\title{
Biochemical indicators in serum of free-ranging roe deer (Capreolus capreolus) in Slovenia
}

\author{
Diana Žele, Gorazd Vengušt \\ University of Ljubljana, Veterinary Faculty, Institute for Breeding and Health Care of Wild Animals, \\ Fish and Bees, Ljubljana, Slovenia \\ Received March 14, 2012 \\ Accepted September 19, 2012
}

\begin{abstract}
The aim of the study was to present the serum biochemical values in free-ranging roe deer as useful indicators of the health status of the animal. Blood samples of 63 roe deer (Capreolus capreolus) were collected during regular annual harvest in Slovenia and analysed for biochemical indicators. The following mean values were recorded: aspartate aminotransferase ( $3 \mu \mathrm{kat})$, alanine aminotransferase $(0.7 \mu \mathrm{kat})$, alkaline phosphatase $(1.5 \mu \mathrm{kat})$, lactate dehydrogenase $(11.8$ $\mu \mathrm{kat})$, gamma glutamyltransferase $(1.9 \mu \mathrm{kat})$, creatine kinase $(16.3 \mu \mathrm{kat})$, urea $(6.3 \mathrm{mmol} / \mathrm{l})$, creatinine $(136.9 \mu \mathrm{mol} / \mathrm{l})$, total serum proteins $(65.5 \mathrm{~g} / \mathrm{l})$, cholesterol $(4.1 \mathrm{mmol} / \mathrm{l})$, triglycerides (2.6 mmol/1), albumin (28.3 g/l), sodium (143.9 mmol/1), chlorine (106.4 mmol/1), calcium (2.5 $\mathrm{mmol} / \mathrm{l})$, inorganic phosphorus $(4.1 \mathrm{mmol} / \mathrm{l})$ and magnesium $(1.6 \mathrm{mmol} / \mathrm{l})$. This is the first report on concentration of serum glutamate dehydrogenase $(0.16 \mu \mathrm{kat})$ and serum iron $(34.9 \mu \mathrm{mol} / \mathrm{l})$ in roe deer. There were no differences in the values of biochemical indicators between males and females $(P<0.05)$. To our knowledge this is the first extended research on this topic in roe deer.
\end{abstract}

Cervidae, wild animal, blood, biochemistry indicators

The roe deer, the most widespread game animal in Slovenia has an important ecologic and economic role. In the last few years we have witnessed an increasing number of animals living in captivity, which is reflected in the health status of this species. The biochemical profiles for many deer species are not available and the values are often compared with values of domestic ruminants, i.e. sheep and goats (Singh et al. 1988; Sahoo and Arora 2002). To date there are only few reports on the serum biochemistry in roe deer (Pav et al. 1975; Ursache et al. 1980; Montané et al. 2002; Nicpoń et al. 2006; HumannZiehank et al. 2008), and most of the available data focused only on some indicators. Serum biochemical data are useful indicators of the health status of the animal and can be used as early warning signs of possible problems in the population regarding feeding and parasite infestation (Mašek et al. 2009).

The aim of this study was to establish the range of biochemical indicators of clinical importance in roe deer.

\section{Materials and Methods}

The study was carried out on roe deer of clinically healthy appearance. The animals were shot during the regular annual harvesting between September and October in the period from 2008 to 2010 under field conditions. The majority of samples were collected in the southern and western part of Slovenia. All animals were adults. According to the hunters' observations no visible changes were noticed on the internal organs during evisceration.

Blood samples were collected from the heart within a few minutes after the animal's death. The samples collected in serum tubes were allowed to clot at room temperature, centrifuged at $1200 \mathrm{~g}$ for 10 min and stored frozen at $-20{ }^{\circ} \mathrm{C}$ until analysis. Many of the collected samples were haemolysed and were therefore rejected at the pre-analysis stage. Finally, a total of 63 samples from 18 males and 45 females were suitable for analysis.

Sera were examined for various biochemical indicators. Calcium $(\mathrm{Ca})$, chloride $(\mathrm{Cl})$, inorganic phosphorus $(\mathrm{aP})$, magnesium $(\mathrm{Mg})$, iron $(\mathrm{Fe})$, sodium $(\mathrm{Na})$, albumin, alanine aminotransferase (ALT), alkaline phosphatase (ALP), aspartate aminotransferase (AST), creatinine, creatine kinase (CK), gamma glutamyltransferase (GGT), lactate dehydrogenase (LDH), total serum protein (TSP) and urea were measured using the RX Daytona biochemical

Address for correspondence:

Gorazd Vengušt

Institute for Breeding and Health Care of Wild Animals, Fish and Bees

Veterinary Faculty, University of Ljubljana

Gerbičeva 60, 1000 Ljubljana, Slovenia

\author{
Phone: +38604779196 \\ Fax: +38602832243 \\ E-mail: gorazd.vengust@vf.uni-lj.si \\ http://actavet.vfu.cz/
}


analyzer (Randox Laboratories Ltd., Ireland). Glutamate dehydrogenase (GLDH) was measured using the COBAS MIRA biochemical analyzer (Hoffman La Roche, Switzerland), with the enzyme assay performed at $37^{\circ} \mathrm{C}$. For comparative purposes, values quoted in some other reports have been converted using the conversion factors described by Kaneko et al. (1997).

For statistical purposes, the data were divided by sex into two groups. Values of the different groups are presented as means \pm standard deviations (S.D.). Statistical analysis (one-way analysis of variation) was performed using the SPSS package (SPSS Inc., Chicago, Illinois, USA) when comparing two sets of data. Two groups were considered significantly different if $P<0.05$.

\section{Results}

All sampled roe deer appeared healthy when shot in the field. Average values of biochemistry indicators (enzymes, substrates, electrolytes and trace elements) detected in the serum of roe deer are summarized in Table 1. No significant differences $(P<0.05)$ were observed between sexes.

Table 1. Average values (mean \pm standard deviation) of biochemistry indicators of free-ranged roe deer $(n=63)$

\begin{tabular}{lccc}
\hline Indicator (unit) & Total animals & Male & Female \\
\hline AST $(\mu$ kat $)$ & $3 \pm 1.8$ & $2.4 \pm 1.5$ & $3.3 \pm 2$ \\
ALT $(\mu \mathrm{kat})$ & $0.7 \pm 0.5$ & $0.7 \pm 0.4$ & $0.7 \pm 0.5$ \\
ALP $(\mu \mathrm{kat})$ & $1.5 \pm 1$ & $1.5 \pm 0.9$ & $1.6 \pm 1.1$ \\
LDH $(\mu \mathrm{kat})$ & $11.8 \pm 7.8$ & $9.1 \pm 5.8$ & $12.7 \pm 10$ \\
GGT $(\mu \mathrm{kat})$ & $1.9 \pm 1$ & $1.6 \pm 0.6$ & $2 \pm 1.3$ \\
GLDH $(\mu \mathrm{kat})$ & $0.16 \pm 0.17$ & $0.1 \pm 0.11$ & $0.2 \pm 0.21$ \\
$\mathrm{CK}(\mu \mathrm{kat})$ & $16.3 \pm 10.6$ & $13.4 \pm 12$ & $17.8 \pm 11.8$ \\
Urea $(\mathrm{mmol} / \mathrm{l})$ & $6.3 \pm 2.7$ & $6.7 \pm 2.1$ & $6.1 \pm 2.9$ \\
Creatinine $(\mu \mathrm{mol} / \mathrm{l})$ & $136.9 \pm 52.9$ & $139.7 \pm 66.8$ & $135.7 \pm 28$ \\
TSP $(\mathrm{g} / \mathrm{l})$ & $65.5 \pm 12.9$ & $62.6 \pm 13.3$ & $66.7 \pm 12.1$ \\
Cholesterol $(\mathrm{mmol} / \mathrm{l})$ & $4.1 \pm 1.8$ & $4.2 \pm 2.7$ & $4.1 \pm 1.6$ \\
Triglycerides $(\mathrm{mmol} / \mathrm{l})$ & $2.6 \pm 1.7$ & $2.3 \pm 1.6$ & $2.6 \pm 1.7$ \\
Albumin $(\mathrm{g} / \mathrm{l})$ & $28.3 \pm 4$ & $27.1 \pm 4.9$ & $28.8 \pm 4.4$ \\
Fe $(\mu \mathrm{mol} / \mathrm{l})$ & $34.9 \pm 10.5$ & $38.2 \pm 14$ & $33.5 \pm 12.3$ \\
$\mathrm{Na}(\mathrm{mmol} / \mathrm{l})$ & $143.9 \pm 10$ & $144.7 \pm 9.6$ & $143.5 \pm 10.4$ \\
$\mathrm{Cl}(\mathrm{mmol} / \mathrm{l})$ & $106.4 \pm 8.1$ & $107.6 \pm 6.9$ & $106 \pm 7.4$ \\
$\mathrm{Ca}(\mathrm{mmol} / \mathrm{l})$ & $2.5 \pm 0.3$ & $2.5 \pm 0.3$ & $2.6 \pm 0.4$ \\
$\mathrm{aP}(\mathrm{mmol} / \mathrm{l})$ & $4.1 \pm 1.5$ & $3.8 \pm 1.5$ & $4.3 \pm 1.7$ \\
$\mathrm{Mg}(\mathrm{mmol} / \mathrm{l})$ & $1.6 \pm 0.5$ & $1.5 \pm 0.5$ & $1.7 \pm 0.5$ \\
\hline
\end{tabular}

AST - aspartate aminotransferase, ALT - alanine aminotransferase, ALP - alkaline phosphatase, LDH - lactate dehydrogenase, GGT - gamma glutamyltransferase, GLDH - glutamate dehydrogenase, CK - creatine kinase, TSP - total serum protein, $\mathrm{Fe}$ - iron, $\mathrm{Na}$ - sodium, $\mathrm{Cl}$ - chloride, $\mathrm{Ca}$ - calcium, aP - inorganic phosphorus, $\mathrm{Mg}$ - magnesium

\section{Discussion}

The haematological investigations have become an important tool in monitoring of the health status of wild animals. However, information on the biochemical profile of roe deer is rather scarce. To our knowledge this is the first extended research dealing with various biochemical values of shot roe deer. The obtained data are difficult to compare with data of other deer studies due to a lack of data in the available literature, the individual variability in enzyme activities, differences in the capture methods, 
season and sex. However, the difficulties associated with evaluating results obtained by a variety of techniques and expressed in different units have been discussed elsewhere (Lumsden 1998).

Serum AST, ALT, LDH and CK activities in this study were lower than the previously reported values (Montané et al. 2002) in captured or transported roe deer. The AST and ALT enzymes are found in many body tissues including the muscle. Following muscle trauma, a rapid release of these enzymes is characteristic (Tennant 1997), which could be closely connected with differences in the serum enzyme concentration depending on how the deer was captured (Wilson and Pauli 1983; Marco and Lavin 1999).

The studies conducted by Goddard et al. (1997) showed LDH to have a high specificity for skeletal muscle in red and fallow deer, and thus a rise in plasma LDH activity might be a useful in vivo marker for muscle damage. Enzyme CK is found primarily in the heart and skeletal muscles and, beside AST, is the most sensitive indicator of muscular disorders (Chapple et al. 1991). Considerable injury to any of these structures will lead to a measurable increase in CK concentrations (Ishak 2004). The activity of ALT, AST, $\mathrm{CK}$ and LDH muscle enzymes has been reported to increase during capture and handling operations in stressed wild ungulates and animals suffering from capture myopathy, as a result of increased muscle cell permeability or cell damage (Montané et al. 2002; Bender 2003; López-Olvera et al. 2007). Similarly a gun shoot wound might cause increased enzyme activity, however, in shot red deer the increased CK activity was non-nsignificant (Kent et al. 1980). Due to these factors, it is essential to take into consideration the method of capture when evaluating or comparing serum chemistry among different studies (Johnson et al. 2010).

The concentration of ALP (1.5 $\mu \mathrm{kat})$ in our study is comparable with those reported by Montané et al. (2002) in captured roe deer. The ALP enzyme is found in all tissues; however, most of its activity derives from the liver and bone (Rogers 1976). Serum ALP activity is usually elevated in young growing animals and in case of liver disease (Tennant 1997).

The average concentration of GGT $(1.9 \mu \mathrm{kat})$ in our study is considerably lower than those reported previously in shot roe deer by Nicpoń et al. (2006). Enzyme GGT activities provide sensitive indications of bile duct and liver injury in animals with fascioliosis (Anderson et al. 1977; Sykes et al. 1980). The higher value reported by Nicpoń et al. (2006) may be associated with liver parasites or laboratory conditions under which the analyses were performed.

There are no data in the available literature on serum GLDH concentration in roe deer. In our study the mean GLDH activity was $0.16 \mu$ kat. The serum GLDH concentrations ranged from 0.005 to $0.5 \mu \mathrm{kat}$. A higher value was reported by Knox et al. (1988) in captured red deer with ranges between 0.2 and $1 \mu \mathrm{kat}$. These data indicate wide individual variation. The reason for that is unknown. Like GGT, concentration activities of GLDH increase in sheep (Sykes et al. 1980) and cattle (Anderson et al. 1977) when the bile duct and liver are damaged.

Serum urea $(6.3 \mathrm{mmol} / \mathrm{l})$ and creatinine $(136.9 \mu \mathrm{mol} / \mathrm{l})$ concentrations are comparable with concentrations reported previously in shot or captured roe deer (Ursache et al. 1980; Montané et al. 2002; Nicpoń et al. 2006). It should be worthwhile to take into consideration that variation in the concentration of creatinine in the serum may depend on the seasonal rhythm of the animal (Eiben and Fischer 1984) and it is positively correlated with muscle hypertrophy in males during the rut (Schnare and Fischer 1987).

The mean concentration of TSP $(65.5 \mathrm{~g} / \mathrm{l})$ was similar to those reported by Ursache et al. (1980) and Montané et al. (2002) in captured roe deer, while Pav et al. (1975) reported a considerably lower value $(42.2 \mathrm{~g} / \mathrm{l})$ in shot roe deer. According to Pav et al. (1975) this could be due to parasite infestation in the studied animals. Mean serum albumin 
concentration (28.3 g/l) is comparable with the values reported by Ursache et al. (1980) in captured and Pav et al. (1975) in shot roe deer.

There are no data in the available literature on serum iron concentration in roe deer. In our study the iron concentration was $34.9 \mu \mathrm{mol} / \mathrm{l}$, which is comparable with reports on other deer species (Kolb et al. 1995) and sheep (Kaneko et al. 1997).

Serum concentrations of sodium $(143.9 \mathrm{mmol} / \mathrm{l})$, calcium $(2.5 \mathrm{mmol} / \mathrm{l})$, chloride $(106.4$ $\mathrm{mmol} / \mathrm{l})$ and magnesium $(1.6 \mathrm{mmol} / \mathrm{l})$ are comparable with previous reports on roe deer (Pav et al. 1975; Ursache et al. 1980; Montané et al. 2002), while inorganic phosphorus concentration $(4.1 \mathrm{mmol} / \mathrm{l})$ was higher than the values reported in roe deer by $\mathrm{Pav}$ et al. (1975) and Ursache et al. (1980). According to Knox et al. (1988), the variation in serum inorganic phosphorus concentration may depend on pasture management or geographical factors; however these differences are difficult to interpret.

The results of this study bring biochemical values in free-ranging roe deer that can be used as useful indicators of the health status of these animals.

\section{Acknowledgments}

This work received financial support from the Research Group P4-0092 financed by the Slovenian Research Agency. The authors wish to acknowledge Marija Nemec M.Sc., DVM for her assistance with the laboratory work and the Slovenian hunters for their help with providing roe deer blood.

\section{References}

Anderson PH, Berrett S, Brush PJ, Hebert CN, Parfit JW 1977: Biochemical indicators of liver injury in calves with experimental fascioliasis. Vet Rec 15: 43-45

Bender HS 2003: Muscle. In: Latimer KS, Mahaffey EA, Prasse KW (Eds): Veterinary Laboratory MedicineClinical Pathology, 4th edn. The Iowa State University Press, Ames, IA, pp. 260-269

Chapple RS, English, AW, Mulley, RC, Lepherd EE 1991: Haematology and serum biochemisty of captive chital deer in Australia. J Wild Dis 27: 396-406

Eiben B, Fischer K 1984: Examination of various blood parameters in fallow deer (Dama dama L.) during the course of the year (German). Z Jagdwiss 30: 235-242

Goddard PJ, Keay G, Grigor PN 1997: Lactate dehydrogenase quantification and isoenzyme distribution in physiological response to stress in red deer (Cervus elaphus). Res Vet Sci 63: 119-122

Humann-Ziehank E, Ganter M, Hennig-Pauka I, Binder A 2008: Trace mineral status and liver and blood parameters in sheep without mineral supply compared to local roe deer (Capreolus capreolus) populations. Small Rumin Res 75: 185-191

Ishak K 2004: Hepatobiliary and skeletal muscle enzymes and liver function tests. In: Meyer DJ, Harvey JW (Eds.): Veterinary laboratory medicine interpretation and diagnosis, 3rd edn. W. B. Saunders Co., Saint Louis, Missouri, pp. 169-192

Johnson D, Harms NJ, Larter NC, Elkin BT, Tabel H, Wei G 2010: Serum biochemistry, serology, and parasitology of boreal caribou (Rangifer tarandus caribou) in the Northwest Territories, Canada. J Wildl Dis 46: 1096-1107

Kaneko JJ, Harvey JW, Bruss LM 1997: Appendixes. In: Kaneko JJ, Harvey JW, Bruss LM (Eds.): Clinical biochemistry of domestic animals. $5^{\text {th }}$ ed. San Diego: Academic Press, pp. 885-905

Kent JE, Chapman DI, Chapman NG 1980: Serum constituents of red deer (Cervus elaphus). Res Vet Sci 28: $55-57$

Knox DP, McKelvey WAC, Jones DG 1988: Blood biochemical reference values for farmed red deer. Vet Rec 122: $109-112$

Kolb E, Lippmann R, Eichler S, Leo M, Rosigkeit H 1995: Biochemical studies of fallow deer (Dama dama L.). II. Plasma concentrations of sodium, potassium, chloride, iron, iron binding capacity, copper and zinc (German). Tierarztl Umsch 50: 626-631

Lumsden JH 1998: "Normal" or reference values: questions and comments. Vet Clin Pathol 27: 102-106

López-Olvera JR, Marco I, Montané J, Casas-Díaz E, Lavín S 2007: Effects of acepromazine on the stress response in Southern chamois (Rupicapra pyrenaica) captured by means of drive-nets. Can J Vet Res 71: 41-51

Marco I, Lavin S 1999: Effect of the method of capture on the haematology and blood chemistry of red deer (Cervus elaphus). Res Vet Sci 66: 81-84

Mašek T, Konjević D, Severin K, Janicki Z, Grubešić M, Krapinec K, Bojanc J, Mikulec Ž, Slavica A 2009 : Hematology and serum biochemistry of European mouflon (Ovis orientalis musimon) in Croatia. Eur. J Wildl Res 55: 561-566

Montané J, Marco I, López-Olvera J, Manteca X, Lavín S 2002: Transport stress in roe deer (Capreolus capreolus): effect of a short-acting neuroleptiv. Anim Welf 11: 295-303 
Nicpoń J, Gawęcki J, Kinal S, Szyszkowska A, Monkiewicz J 2006: Alimentary value of fodder constituting feeding ground for deer, level of metabolites of protein-energy changes in the contents of rumen and selected blood parameters. EJPAU 9:15. http://www.ejpau.media.pl/volume9/issue2/art-15.html). Accessed 10 May 2006

Pav J, Zajiček D, Dvorak M 1975: Clinical examination of the blood of roe deer (Capreolus capreolus L.) and fallow deer (Dama dama L.) naturally invaded by parasites (in Czech). Vet Med (Praha) 20: 215-221

Rogers WA 1976: Source of serum alkaline phosphatase in clinically normal and diseased dogs: a clinical study. J Am Vet Med Assoc 168: 934-937

Sahoo A, Arora BM 2002: Haematological and blood biochemical profile of spotted deer (Axis axis) reared in semi-captive environment. Indian J Anim Sci 72: 762-765

Schnare H, Fischer K 1987: Secondary sex characteristics and connected physiological values in male fallow deer (Dama dama L.) and their relationship to changes of the annual photoperiod: Doubling the frequency. J Exp Zool 244: 463-471

Singh SK, Joshi BP, Rai P 1988: Haematological studies of some wild artiodactylids of North Indian Zoo. Indian J Anim Sci 65: 644-647

Sykes AR, Coop RL, Robinson MG 1980: Chronic subclinical ovine fascioliasis: plasma glutamate dehydrogenase, gamma-glutamyl transpeptidase and aspartate aminotransferase activites and their significance as diagnostic aids. Res Vet Sci 28: 71-75

Tennant BC 1997: Laboratory assessment of hepatic function. In: Kaneko JJ, Harvey JW, Bruss LM (Eds): Clinical biochemistry of domestic animals, $5^{\text {th }}$ edition. San Diego, Academic Press, pp. 337-352

Ursache O, Chevrier L, Blancou JM, Jaouen M 1980: Value of haematological and biochemical parameters in roe deer (Capreolus capreolus). Rev Med Vet 131: 547-552

Wilson PR, Pauli JV 1983: Blood constituents of farmed red deer (Cervus elaphus). 2: Biochemical values. NZ Vet J 31: 1-3 